\title{
O RETRATO MORAL E POLÍTICO DE GRANDES FIGURAS DA HISTÓRIA NA BIBLIOTECA HISTÓRICA DE DIODORO DE SICÍliA
}

Cynthia Cristina de Morais Mota ${ }^{1}$

\section{Resumo}

$\mathrm{O}$ artigo trata da importância dada à guerra pelos historiadores da Antiguidade como parte importante de sua construção narrativa e da descrição dos feitos dos grandes homens. Busca-se aprofundar a importância da guerra para a construção de homens considerados sábios e importantes para o historiador Diodoro de Sicília visto que a história é, para ele, um tribunal, onde todos serão julgados para o bem ou para o mal.

\section{Palavras-chave}

Guerras na Antiguidade; historiografia helenística; Diodoro de Sicília; Epaminondas; Tebas.

\begin{abstract}
The article deals with the importance given to the war by historians of antiquity as an important part of his narrative construction and description of the deeds of great men. It seeks to deepen the importance of the war for the construction of men considered wise and important to the historian Diodorus of Sicily as the story is, for him, a court, where everyone will be judged for good or for evil.
\end{abstract}

\section{Keywords}

Wars in Ancient World; Hellenistic Historiography; Diodorus of Sicily; Epaminondas; Thebes.

\footnotetext{
1 Professora Doutora, Universidade Federal de Rondônia, Rolim de Moura, Brasil. E-mail: cythiacristina@unir.br
} 
O fim último da guerra deve ser a paz. Aristóteles. Política, VII, 1333a.

O único motivo para empreender a guerra é o desejo de viver em paz sem injustiça. Cícero, De officiis, 11, 34.

\section{A guerra, forjadora de Grandes Homens: o papel de parádoxa (inesperado) e da Fortuna ( $t y ́ c h \bar{e})$ na compreensão da História na Biblioteca Histórica de Diodoro de Sicília}

Embora seja um truísmo, o mundo antigo, como um todo, foi marcado intensamente pela guerra. Os grandes impérios da Antiguidade baseavamse na conquista contínua de povos e territórios, com uma violência assustadora. Os assírios, notórios pelo uso contínuo e sistemático da violência, promoviam matanças e deportações em massa das populações vencidas. Na Mesopotâmia, em suas diversas fases históricas, as guerras tiveram papel fundamental na tomada (e destruição) de cidades e povos. Populações inteiras viviam à mercê de guerras incessantes e intermináveis: qualquer estabilidade política era sempre transitória, uma vez que aquela dependia dos sucessos dos reis e líderes nos campos de batalha. Uma rápida leitura dos textos que compõem o Antigo Testamento bíblico mostranos que Iahweh era, sobretudo, o deus ligado à guerra, e um de seus epítetos era "Iahweh, Senhor dos Exércitos". Tal imagem nos remete também ao componente sagrado, presente nos atos guerreiros, com cerimônias e sacrifícios ofertados aos deuses, além da existência de deuses que tinham como principal prerrogativa serem coparticipes dos atos que envolviam a guerra. Os reis mesopotâmicos acumulavam funções guerreiras e religiosas e ambas estavam estreitamente interligadas. Rituais eram realizados com o objetivo de agradar-lhes para que esses permanecessem ao lado do exército, contra os inimigos. Como reconhecimento pelas vitórias conquistadas, parte do butim de guerra era ofertada aos santuários e aos deuses. Passagem significativa, que mostra a importância da intercessão divina nas batalhas, é a conquista de Jericó efetuada por Josué (Josué, 5, 13-27) 2 ${ }^{2}$. Complexos rituais eram efetuados, juntamente com os sacerdotes, para que a cidade pudesse ser conquistada. Todos os elementos simbólicos que contribuem para a sacralização da guerra e da violência que ela gera encontram-se justificados no anátema, ou

\footnotetext{
2 "Mas vós, guardai-vos do anátema, para que não tomeis alguma coisa do que é anátema, movidos pela cobiça, pois isso tornaria anátema o acampamento de Israel e traria sobre ele confusão. Toda prata e todo ouro, todos os objetos de bronze e de ferro serão consagrados a Iahweh; entrarão no seu tesouro."
} 
seja, a parte que cabe ao deus daquilo que foi conquistado, graças à sua divina intervenção. Embora não se possa generalizar o comportamento de todos os povos, colocando-os sob a mesma perspectiva interpretativa, é fato que a religião exerceu papel decisivo para a justificativa de matar (com todas as consequências morais que isso acarreta) e de se apossar dos bens do adversário. Era preciso toda uma série de incentivos para que um homem se empenhasse em combate direto com outro homem. A presença divina era requerida e mesmo necessária para que tais empreendimentos obtivessem sucesso. Na Ilíada, os deuses estão de tal forma presentes que os heróis apenas realizam aquilo que eles já haviam planejado:

Disse-lhe [a Hera], indignado, que as nuvens do Olimpo cumula: "Deusa implacável, que ofensa tão grave de Príamo e os filhos te compungiu para, assim, te afanares, com tanta insistência, em destruir a cidade de Tróia, de bela feitura? Se conseguisses entrar a cidade potente e suas portas, e, vivo, Príamo e os filhos dos troianos comessem, provavelmente acalmarás a fúria que o peito te abrasa. Faze conforme o desejas: não seja esta rixa motivo de originar-se entre nós, em futuro, discórdia insanável. Ora, outra coisa te quero dizer; guarda-a bem no imo peito: caso me ocorra o desejo, em qualquer ocasião, de algum burgo vir a destruir, habitado por homens, que a ti sejam caros, deixa-me agir livremente, não quero que venha a obstar-me. Entre as cidades que os homens nascidos da terra construíram sob a luz viva do Sol e as estrelas do Céu refulgentes, nenhuma tanta prezava como Ílio de muros sagrados, bem como Príamo e o povo do velho monarca lanceiro. Em meus altares jamais sacrifícios faltaram, nem libações, nem perfumes, as honras, em suma devidas (IV, 30-49).

Embora Homero não descreva a Guerra de Tróia, fica claro no poema o papel significativo dos deuses no desenrolar dos acontecimentos parelos à guerra. É preciso agradar-lhes com sacrifícios e libações, para que os mesmos permaneçam com eles nos momentos decisivos, o que, tanto na épica quanto na historiografia, significava estar junto do guerreiro no momento da batalha e no seu ápice, o recontro.(Clausewitz, 2003: 107). Os sacrifícios são essenciais, como bem denota o diálogo entre Zeus e Hera. Jacqueline de Romilly (Romilly, 1998: 74-75) mostra como a Ilíada, mesmo sendo uma obra que trata de guerra, não contém relatos de batalhas. A maior parte do poema é centrada em narrativas de combates singulares, apresentados em seqüência: não há encadeamento que situe as batalhas em uma ordem. O que se ressalta, sobretudo, é o papel do herói e a glória por ele alcançada.

Homero conta sempre que tipo de arma é empregado, que órgão ela atinge, que tipo de morte resulta disso, não deixando de destacar os ferimentos curiosos, de efeito espetacular e imprevisto. $O$ interesse dessas descrições, portanto, não é apenas moral, mas também técnico. Contudo, tanto em um domínio como no outro, é ao valor do indivíduo que se dirige toda a atenção. Mais uma vez, convém fazer uma ressalva, pois esses aristeîai, que são os combates homéricos, são adulterados, aos nossos olhos, por uma circunstância notável: aquele que põe a 
coragem ou o temor no coração do combatente, que dirige a lança ou a desvia é, com grande freqüência, um deus. Quando estimamos estar indo para um resultado certeiro, descobrimos que isso "teria com certeza acontecido, se nesse momento um deus..." não houvesse interferido. (Romilly, 1998: 74-75)

Dois aspectos importantes ressaltados por Romilly serão adicionados às narrativas dos futuros historiadores, quando forem tratar sobre a guerra: a importância de uma determinada figura no curso da batalha (que tipo de o comportamento o comandante e seus soldados tiveram, como lutaram, e se alcançaram a glória) e o papel do imprevisto, do inesperado nos negócios humanos (que evidencia-se mais claramente na guerra, uma vez que a temática era a preferida dos historiadores gregos). No caso homérico, o inesperado é representado pela intervenção direta dos deuses (mesmo que disfarçados), mas, mesmo em Heródoto, os deuses não deixam de intervir, principalmente pela conversação com eles empreendida através dos oráculos (Romilly, 1998: 74-75) (que aparecem durante todas as Histórias) ou na figura da Divina Providência (Heródoto, III, 108, toû theíou he pronoíê) que organiza e dá sentido à natureza (phýsis). Legrand, editor e tradutor de Heródoto para as edições Budé, comenta que, desde o século VI, a ideia de uma inteligência regendo o universo aparecia na filosofia do eleata Xenófanes de Colofão (nóou phrení pánta chradainei) e foi depois retomada especialmente por Anaxágoras. (Herodote, 1967: 150) Heródoto refere-se à Divina Providência em uma descrição que faz dos animais da Arábia, região infestada de serpentes: a Divina Providência desempenha papel regulador na natureza posto que, com sua imensa sabedoria, fez com que animais peçonhentos como a serpente, tivessem pouca fecundidade; um mundo que fosse infestado por animais de tal espécie seria terrível para a existência humana. Já animais inofensivos como a lebre, por exemplo, eram extremamente fecundos de modo que pudessem servir de alimento para os outros. Sem dúvida, é uma racionalização da intervenção divina, tanto na esfera humana quanto na natureza, visto que a Divina Providência age com "naturalidade" para que as coisas se organizem da melhor maneira possível e, assim, beneficia a todos. Mas não esperemos demasiadamente de Heródoto, pois o autor dá aos deuses uma grande importância em sua narrativa, mas não exatamente da maneira com que Homero fez. Tomemos como exemplo uma passagem bastante significativa das Histórias:

Vê como a divindade fulmina com seu raio os animais de grande porte, sem permitir que eles se ostentem, enquanto não faz qualquer mal aos pequenos. Vê como ela atinge sempre com seus dardos as casas e as árvores mais altas; de fato, a divindade se compraz em rebaixar tudo que se eleva. Pela mesma razão, um exército numeroso às vezes é aniquilado por um pequeno, quando, por exemplo, a divindade invejosa (thèos phitonésas) inspira-lhe um terror pânico ou o apavora com o ribombar dos trovões, a tal ponto que ele é humilhantemente dizimado. Em verdade, a divindade não admite pensamentos altaneiros a não ser em si mesma. 
Em todas as circunstâncias, a precipitação engendra erros dos quais nascem habitualmente grandes desastres; contemporizar, ao contrário, traz vantagens, e se não as percebermos imediatamente, será possível descobri-las no devido tempo (VII, 10).

É preciso sabedoria para perceber sinais que denotam o momento em que os deuses enviam "mensagens", pois nem todos estão preparados para decodificar tais signos. Essa cegueira é muitas vezes causada pela hýbris, que impede o homem de enxergar a verdade que está para acontecer de maneira iminente, incapacitando-o com seu orgulho, de se colocar no seu devido lugar. ${ }^{3}$ Dada a notória preferência da historiografia grega em narrar eventos ligados à guerra, nota-se que, para além da competência individual, demonstrada pelos generais nos campos de batalha, essa não é, entretanto, mérito exclusivamente seu. Muitas vezes, os acontecimentos não ocorrem de acordo com o planejado, visto que o acaso presente nos negócios humanos atesta que todos estão sujeitos aos revezes da existência. Entretanto percebe-se que os "acasos" não são completamente aleatórios. $\mathrm{O}$ acaso, representado pela palavra grega týchè, é uma deusa encontrada n'A teogonia de Hesíodo e faz parte da linhagem de Urano e Tétis (360). Desde o século IV a deusa era cultuada nas cidades de Tebas, Atenas, Megara e Megalópolis (terra de Políbio, autor que confere à Fortuna papel importante em sua obra) sob o nome de Agathé Tychēe (Pötscher, 1979: 1016-1017). Contudo o acaso não é o único significado possível de tychē: pode implicar sentidos contraditórios como destino, felicidade ou ainda, infelicidade. Está implícita a ideia de que algo inesperado pode acontecer e, portanto, não era menos importante para os homens a ela render culto em uma tentativa de controlar, ainda que de maneira provisória, o lote destinado a cada um, na roda interminável de acontecimentos da vida, como bem lembrou Heródoto ao justificar sua narrativa:

não vou afirmar que as coisas [a sucessão de raptos que culminaram na Guerra de Tróia] se passaram assim ou de outra maneira, mas, depois de assinalar aquele que eu próprio sei ter sido o primeiro a cometer atos injustos contra os helenos, avançarei na narrativa, examinando indistintamente as pequenas e as grandes cidades dos homens. Das que antigamente eram grandes, muitas delas se tornaram pequenas, enquanto as que no meu tempo são grandes, eram primeiro pequenas. Persuadido de que a felicidade (eudaimonién) humana nunca permanece firme no mesmo ponto, mencionarei por igual umas e outras (I, V). (Tradução de Maria de Fátima Silva e José Ribeiro Ferreira.)

De fato, juntamente com a Fortuna, estão associados moîra pótmos (destino personificado, imperioso, inflexível e que leva toda coisa a seu fim, Ilíada,

\footnotetext{
3 Parece ser quase uma regra a "cegueira" dos sinais tão claramente enviados pelos deuses.
} 
24, 209) ${ }^{4}$, agathós (Liddel-Scott-Jones, 1989) ${ }^{5}$, daimōn ${ }^{6}$, o que lhe confere um tom muitas vezes sobrenatural da interferência divina, demostrando que o homem não controla seu destino. Ao mesmo tempo, a inclusão da Fortuna na narrativa dá ao historiador grande liberdade para manejar o desenrolar dos acontecimentos, de acordo com sua perspectiva metodológica e suas crenças pessoais em relação ao papel da história e o destino de seus principais personagens. $\mathrm{O}$ caso de Políbio é bastante ilustrativo:

Com efeito, a originalidade de minha obra e o aspecto mais notável de nossa época consistem justamente nisso; a Fortuna (týchē) encaminhou por assim dizer todos os acontecimentos mundiais em uma única direção e os compeliu a orientarse para um só e mesmo escopo; da mesma forma, um historiador deve apresentar diante de seus leitores em sua sinopse os eventos graças aos quais a Fortuna (týchē) produziu esses efeitos em toda parte para atingir seu objetivo global.[...] Considero necessário, portanto, não deixar passar despercebida ou caída no esquecimento a mais bela e instrutiva obra da Fortuna (týchē). Realmente, embora esteja produzindo sempre algo de novo e intervindo na vida humana, em nenhuma outra circunstância a Fortuna (týchē) jamais realizou tal obra nem encenou tal espetáculo como em nossa época (Histórias, I, 4).

Políbio enxerga a vitória irremediável do poderio romano e vê na Fortuna a única força capaz de explicar tão rápida ascensão. A Guerra Anibálica, que poderia ter facilmente levado Roma à derrocada foi, pelo contrário, a oportunidade de os romanos de mostrarem seu gênio e de não se deixarem abater, mesmo nos grandes infortúnios, e, sobretudo, de saber manejar o "inesperado" a seu favor. Quem diria que Aníbal derrotaria o exército romano tão fragorosamente? E mais ainda, que os romanos seriam capazes de reconstituir um exército destroçado, impor uma derrota e aniquilar o poderio cartaginês sobre todo o Mediterrâneo? Tal é o espanto de Políbio, que o leva a creditar também à Fortuna ${ }^{7}$ e ao modo como os homens lidam com ela, o sucesso dos romanos. Longe de ser um elemento "neutro", a

${ }^{4} \mathrm{Na}$ Teogonia, Moira é filha de Zeus e Têmis encarregada dos assuntos dos mortais (904). Mas Hesíodo também a coloca como filha da Noite (que as pariu sozinha): "pariu as Partes e as Sortes que punem sem dó: Fiandeira, Distributriz e Inflexível que os mortais tão logo nascidos dão os haveres de bem e de mal, eles perseguem transgressões de homens e de deuses e jamais repousam as deusas de terrível cólera até que deem com o olho maligno naquele que erra" (218-222). As deusas eram invocadas quando era necessário proferir um juramento.

5 A palavra agathós possui vários significados, como nobre e de bom nascimento; entretanto, encontramos também no sentido religioso como algo favorável, propício e benevolente: "hó agathós daímōn" ou agathē týchè (ou em latim, a "boa deusa", bona dea).

${ }^{6}$ Deus ou deusa (Ilíada, I, 222) ou semelhante a um deus; com a assistência de um deus, pelo favor de um deus (katà daímona, Heródoto, I, 111); de acordo com o agrado dos deuses, a vontade dos deuses, ao acaso (juntamente com a týchē [týchēn kaì daímonas]), a fortuna, o acaso, a sorte.

7 Políbio discute também o papel das constituições para analisar como cada povo se tornou (ou não) poderoso politicamente. Por motivos óbvios, não tratarei desta questão. 
utilização da Fortuna permite ao historiador narrar sobre os mais diversos destinos de figuras importantes, sem tomar partido de alguém ou de alguma cidade, de maneira tão explícita. Afinal, se as coisas tiveram um determinado fim e não outro, não foi "acaso" ou o "destino implacável" que fez com que as coisas tenham acontecido exatamente como deveriam acontecer? Se a Fortuna tem em si o componente do inesperado, ela serve também como "ferramenta" para a "neutralidade" de quem escreve a história. Os historiadores gregos gostavam de encadear sua narrativa de modo que o relato ganhasse uma ideia de continuidade, mesmo que os eventos narrados pudessem ter ocorrido em épocas ou locais diferentes no tempo e espaço. Isso fazia com que o elemento inesperado pudesse ganhar relevo e conferir sentido à narrativa, até mesmo quando, aparentemente, tais eventos não se ligavam.

\section{Diodoro e a Biblioteca Histórica}

Diodoro de Sicília nasceu em Agírion, na Sicília, a oeste do Etna (também conhecido como Diodoro de Agírion, conforme alguns autores), em torno do ano 90. 8 Por intermédio de seus contatos com os romanos que habitavam a ilha, aprendeu a língua latina, o que facilitou suas pesquisas nos arquivos (I, IV, 4). Praticamente tudo o que sabemos sobre sua vida nos é relatado por ele mesmo na Biblioteca Histórica (BH). (Canfora, 2001: 61) ${ }^{9}$. Diodoro levou trinta anos para escrever sua obra, o que lhe custou muitas dificuldades (I, IV, 1). De acordo dom Farrington apud Lens-Tuero (1994: 33) supõe que ele tenha sido um homem independente economicamente, já que podia dispor de tempo livre para pesquisas e viagens. Conheceu o Egito, onde permaneceu por quatro anos e pesquisou na mais importante biblioteca do mundo antigo: Alexandria. A Biblioteca de Diodoro era constituída de 40 livros, cuja estrutura é explicada pelo próprio autor no proêmio (BH, I, I-VI): os seis primeiros tratam das narrativas míticas anteriores à Guerra de Tróia: os três primeiros são consagrados inteiramente aos povos não gregos e os três últimos, quase exclusivamente aos gregos; os próximos onze livros tratam da história universal da Guerra de Tróia até a morte de Alexandre Magno; os vinte e três livros restantes narram os acontecimentos relativos à sucessão de Alexandre e à partilha do Império até a Guerra das Gálias, empreendida por Júlio César (I Consulado). (Spoerri, 2001: 739) A última data citada por Diodoro diz

\footnotetext{
8 Todas as datas citadas no presente trabalho são anteriores à época comum, salvo quando ditas explicitamente.

${ }_{9}^{9}$ Nome dado por Plínio, O Velho, de forma bastante jocosa, procurando descaracterizar a importância de Diodoro como historiador: "Estante da história"; "Entre os gregos, foi Diodoro que deixou as extravagâncias de lado e intitulou sua história de Biblioteca".
} 
respeito à colonização de Tauromênion, empreendida no reinado de Otávio (XVI, VII, 1), podendo ser provavelmente datada em torno dos anos 36/21 antes da época comum. Para Albrecht: 1979, seria o ano 21a.C e para Meister (1997) 36 a.C. ${ }^{10}$ Parte considerável da Biblioteca Histórica de acordo com (Howatson, 1993) não chegou até nós. Restam, de forma integral, os livros I de a VI e de XI a XX, mas há fragmentos de quase todos os outros livros perdidos, conforme atesta a edição inglesa da Loeb Classical. Os fragmentos e excertos (excertos de Constantinopla, Excerpta Hoescheliana para os livros de XXI a XXVI e Fócio, a partir do volume XXXI) (Meister, 1997) e toda a obra de Diodoro são motivos de controvérsia para o estabelecimento das fontes utilizadas por ele. ${ }^{11}$

Diodoro, nesse ponto, não é diferente de seus antecessores: aprecia e dá preferência aos relatos de batalha, descrevendo comportamentos de seus personagens; entretanto, sendo nosso historiador um moralista que exorta seus leitores à virtude, dá preferência, em sua narrativa, ao papel desempenhado por algumas figuras em especial, com as quais claramente se identifica. ${ }^{12}$ Essas narrativas acontecem com bastante freqüência nos chamados livros históricos, ou seja, a partir do livro XI (os livros com narrativas históricas [após a Guerra de Tróia] que restam integrais até o volume $X X)$. De maneira impressionante, os personagens de Diodoro são, de certa maneira, "biografados", porque a história é o tribunal onde todos devem ser julgados pelos atos realizados, para o bem ou para o mal. Tais biografias tendem a mostrar os juízos de valor que Diodoro faz dos personagens, e fica clara sua "simpatia" e "antipatia" em relação aos mesmos. As passagens escolhidas são as que contêm os termos parádoxa com o sentido de "inesperado" ou "contrário a toda expectativa"; tais passagens mostram ainda a intervenção da Fortuna ou da Divina Providência, retratando que tais indivíduos foram merecedores de algum tipo de intervenção inesperada e, por vezes, sobrenatural. Para compreendermos como Diodoro trata tais personagens e o papel que eles ocupam em sua história educativa, é necessário analisar alguns desses personagens que desempenharam papel importante em sua narrativa a ponto de deixar de lado sua preocupação com a "simetria".

\footnotetext{
${ }^{10}$ A questão das datações na Biblioteca Histórica também é motivo de controvérsias entre os estudiosos. Várias datas citadas por Diodoro estão incorretas.

${ }^{11}$ Não pretendo discutir tais controvérsias no escopo deste texto apenas mencioná-las.

12 Do ponto de vista de suas concepções de história.
} 


\section{Modelos humanos na Biblioteca Histórica: o caso Epaminondas e o destino de Tebas}

Os modelos humanos a que Diodoro se dedica em sua Biblioteca Histórica são, naturalmente, chefes guerreiros, generais que comandam exércitos e influenciam seus subordinados, pelo exemplo concreto de suas vidas. A figura do líder guerreiro destemido e que luta junto com seus homens, exortando-os à luta, foi central para que a guerra obtivesse sucesso; para além das recompensas materiais (que sempre existiram), era necessário um forte componente simbólico, que fazia com que o soldado entregasse sua vida ao líder e, por ele fizesse qualquer coisa, até mesmo dar sua vida. Do ponto de vista psicológico, a liderança precisa expressar certos valores, de modo a realçar determinadas virtudes, que seria desejável ao líder possuir: rigidez corporal, coragem, percepção dos interesses alheios, busca do bem, capacidade de suportar a adversidade. $O$ general ou estratego é aquele que deve servir como exemplo, pois necessita disciplinar e cuidar bem de seus subordinados, ser capaz de articular-se com outros líderes (chefes de Estado ou generais) e saber quebrar as articulações dos chefes adversários ou, ainda, atrair o adversário para o seu lado. ${ }^{13}$ É no campo de batalha que se afiguram as qualidades do indivíduo, posto que lá as condições de existência e sobrevivência estão no limite. Os homens dependem extremamente do seu companheiro e de seu comportamento no decorrer da batalha. Desse modo, as relações e a camaradagem que se criavam nos longos anos em que serviam juntos chamou a atenção dos historiadores gregos para a narrativa privilegiada das guerras em suas obras. Os exemplos na Biblioteca Histórica abundam em pequenas "biografias", mas não no sentido convencional do termo tendo em vista que só interessam a Diodoro as qualidades mostradas no decorrer da batalha - permitem compreender como nosso autor vê seu comportamento no período mais grave da existência, ou seja, quando está sendo testado sob todos os aspectos, no momento em que realmente pode perder sua vida e a de seus soldados. O modo como a tropa vê seu general é de extrema importância para que seu sucesso como líder gere o respeito necessário para que possa comandar. A imprudência e a insolência de Pérdicas, por exemplo, acabou por fazê-lo perder a vida através das mãos de seus próprios soldados. Sua luta com Ptolomeu, filho de Lagos, foi marcada por momentos de extrema tensão, tendo o

13 Agradeço imensamente a ajuda fornecida pelo subtenente do Exército Fernando Antônio Lucas Camargo através de conversas ou indicações bibliográficas. Profundo conhecedor da história militar pôde me ajudar a compreender certos aspectos da liderança e hierarquia militar e dos aspectos psicológicos implícitos na liderança dos generais sobre os soldados. 
Nilo por cenário. Pérdicas pretendia dominar o Egito de Ptolomeu a todo custo e não hesitou em tomar decisões temerárias, colocando toda sua tropa em risco. Configurou seu exército da seguinte forma: na ala esquerda, dispôs os elefantes e na ala direita, os cavalos, de modo que os soldados de infantaria pesada pudessem ser recolhidos e levados sãos e salvos para o outro lado do rio. Mas um fenômeno inesperado (parádoxon) e singular ocorreu, assim que começou a travessia do rio: se os primeiros soldados o atravessavam sem maiores problemas, os seguintes começaram a afundar completamente, causando uma confusão geral. Ao cruzar o vau do rio, com enorme quantidade de peso, as tropas transformaram esse trecho em uma espécie de areia movediça, que fez com que a roupa militar, com suas couraças extremamente pesadas, impelissem-nos ainda mais para o fundo. Houve pânico generalizado, pois muitos não sabiam nadar; os soldados, na tentativa desesperada de se livrar da pesada indumentária militar, afogavam-se. Nesse momento, os crocodilos apareceram e atacaram os soldados, matando-os impiedosamente. Cerca de dez mil soldados pereceram, sem que nenhuma batalha houvesse sido travada. Ptolomeu ${ }^{14}$ e suas tropas, que a tudo assistiam do outro lado do rio, ainda socorreram vários soldados, o que colocou Pérdicas em uma situação totalmente embaraçosa. Revoltados, alguns soldados, no meio da noite, invadiram a tenda de Pérdicas e o assassinaram (Biblioteca Histórica, XVIII, XXXIV-XXXVI). A sabedoria de Ptolomeu fê-lo perceber que, além de lutar com as antigas tropas de Alexandre (e, que, portanto, conhecia bem) não seria prudente e, atravessar o Nilo seria praticamente impossível, devido às suas barreiras naturais (como a forte correnteza do Nilo e os temíveis crocodilos). Pérdicas, por outro lado, foi incapaz de pensar no bem-estar de seus soldados, desejoso que estava de vencer Ptolomeu e, assim, essa cegueira fez com que perdesse seu bem mais precioso enquanto general: a confiança de seus homens. Sua ambição desmedida pelo poder e comando supremo do legado de Alexandre não o deixou perceber os sinais e a aparente "calma" de Ptolomeu nada mais era do que prudência.

Tais disparates não foram cometidos pelo grande Epaminondas, o general tebano responsável por duas vitórias espetaculares sobre o invencível exército espartano em Leuctras e Mantinéia. Seu portrait ganha páginas memoráveis na Biblioteca Histórica. Diodoro utiliza os artifícios da retórica e do discurso direto para melhor ressaltar as qualidades de Epaminondas, que dedicou sua vida a Tebas. A cidade era

${ }^{14}$ E levou a fama para Diodoro, de philoanthrōpos. 
mal vista pelo conjunto das póleis gregas, devido ao fato de ter permanecido, durante as Guerras Pérsicas, ao lado do inimigo. Mas o célebre estratego que fora educado na filosofia pitagórica, sendo responsável pela derrota do exército espartano ${ }^{15}$ - fato inédito e que causou grande comoção e espanto em toda a Grécia -, fez com que, mesmo aqueles que não vissem Tebas sob um viés positivo, tivessem, pela sua pessoa, profunda admiração. Se Epaminondas era um general dotado de todas as qualidades de bravura e coragem, não ficava a dever também na astúcia. Um presságio mandado pela divindade advertiu aos lacedemônios que perderiam sua hegemonia na Grécia, a qual, segundo Diodoro, já durava quinhentos anos, e perderiam também seu império. De fato, observou-se no céu a passagem de um cometa, que, durante várias noites, brilhou como uma bola de fogo e, pouco tempo depois, ocorreu uma batalha, que terminou de maneira inesperada (paradóxos) para os espartanos, contra toda a expectativa (anelpístōs) (Biblioteca Histórica, XV, L, 1-2). Filósofos naturalistas (phisikàs) procuraram uma explicação para tal fenômeno, sustentando que ele era fruto de causas naturais; os caldeus da Babilônia e outros astrólogos já haviam previsto, com sucesso, tais acontecimentos, devido ao ciclo particular que cada astro realizava eternamente na sua revolução, segundo um curso determinado. Portanto os sábios não se haviam surpreendido (thaumázein) com tal acontecimento (Biblioteca Histórica, XV, L, 3). ${ }^{16}$ Diodoro ressata que essa "tocha de fogo" no céu foi de tão grande

15 Diodoro afirma que os lacedemônios pretendiam escravizar os tebanos e, nesse momento, os gregos ficaram divididos. Alguns achavam que seria ótimo se os tebanos assim o fizessem, mas outros foram tomados de compaixão por eles. As colocações de Diodoro são sintomáticas: ele adianta a narrativa dizendo que muitos mostravam compaixão "pelas desgraças que os aguardavam" (BH, XV, LI, 3): ou seja, a destruição de Tebas por Alexandre Magno, descrita de maneira pungente no livro XVII. Penso que Diodoro se esforça para ressaltar em sua $\mathrm{BH}$ a importância desse momento para os tebanos por solidariedade aos mesmos, devido aos grandes sofrimentos de que serão vítimas.

16 Momento semelhante pode ser observado em XV, LXXX, 2-3, quando Pelópidas (general tebano) iria marchar com seu exército, ocorreu um eclipse do sol. Muitos acharam tal fenômeno inquietante e afirmavam que com a partida dos soldados, era o sol que cobria a cidade que se eclipsou: através dessas palavras, previam a morte de Pelópidas; entretanto, o mesmo não se inquietou: era seu destino que deveria ser cumprido. De fato, Pelópidas morreu no campo de batalha, mas apesar de sua morte, ele havia conseguido alcançar grande glória (dóxes) além de ter contribuído sobremaneira para a ascensão tebana. Diodoro arremata: "Damos assim a Pelópidas, que mereceu, por seu valor pessoal, a consideração de todos, o elogio que lhe deve a História" (BH, XV, LXXXI, 4). Ele gosta sempre de afirmar: "Não deixamos jamais de dizer às pessoas de bem, quando de sua morte [àqueles que tombaram em campos de batalha], o elogio que lhe era devido" (BH, XV, LXXXVIII, 1). 
luminosidade, que fez sobre a terra uma sombra só comparável à da lua. Epaminondas realizou várias campanhas contra o Peloponeso com o objetivo de isolar Esparta, e teve como resultado a libertação da Messênia (Biblioteca Histórica, XV, LXVII, 1, "de maneira inesperada" paradóxous), fazendo com que os lacedemônios perdessem um terço de seu território. Na famosa batalha de Leuctras, os tebanos marcharam em direção ao exército inimigo, mas ficaram assustados com o tamanho do exército espartano. Os beotarcos fizeram uma reunião a fim de discutir se seria realmente interessante realizar uma batalha, contra um exército muito superior ao deles. O grupo de estrategos dividiu-se, cabendo a Epaminondas o "voto de Minerva". Como não desejou decidir sozinho algo tão importante, Epaminondas utilizou um estratagema, tendo em vista saber do temor supersticioso dos presságios em que os soldados acreditavam. Escolheu os melhores homens da Beócia em idade para servir, contando no total seis mil homens; ao sair da cidade, encontrou um arauto que havia assinalado que um escravo cego havia fugido. Epaminondas disse, como era o costume, que se procurasse o escravo para restituí-lo ao dono. Mas os velhos soldados viram o acontecimento como um presságio funesto que anunciava o futuro; os jovens não diziam nada, com medo de parecerem fracos, mas Epaminondas respondeu para todos aqueles que estivessem levando em conta o presságio: “Defender a pátria é o único bom presságio" (Ilíada, XII, 243, verso proferido por Heitor). Entretanto os soldados mais velhos, que já haviam visto muita coisa acontecer, protestaram vivamente, afirmando não quererem os deuses que o exército tebano prosseguisse. Depois daquela declaração, Epaminondas nada mais disse, na plena convicção de que a consideração ao belo (kalôn) e o cuidado do justo (dikaíon) era o melhor presságio (sèmeíon). Embora muitos condenassem a atitude de Epaminondas naquele momento, foram obrigados depois da vitória sobre os lacedemônios, a reconhecer sua excepcional inteligência na arte militar e que havia prestado à sua pátria grandes serviços. De fato, para Diodoro, somente os grandes homens são capazes de ir contra a opinião do senso comum e, contra toda a expectativa (parádoxos), triunfar magnificamente. Em seus relatos de batalha (nos livros "históricos"), o papel do líder sempre se mostra importantíssimo para o resultado final. Após a batalha de Leuctras, as forças de Epaminondas massacraram inúmeros fugitivos e alcançaram uma magnífica vitória: eles haviam lutado contra os melhores da Grécia e os haviam vencido, contra toda expectativa (paradóxos), com apenas um punhado de homens e uma tropa bem menor do que a dos lacedemônios; no curso da batalha, mataram ao menos quatro mil soldados espartanos e foram mortos 
pouco menos de trezentos tebanos. A morte de Epaminondas é narrada de maneira comovente: quando, já à morte, no campo de batalha (como todo herói deve morrer), perguntou se haviam salvado seu escudo, alguém respondeu que sim, o herói pergunta, ainda, quem havia vencido a batalha e os soldados respondem que tinham sido os tebanos - Epaminondas afirmou que era "um bom momento para morrer". Todos à sua volta choravam e se lamentavam por tão triste perda, principalmente porque Epaminondas morreria sem ter tido a oportunidade de ter filhos. Mas o herói respondeu: "Não, por Zeus, eu deixo dois filhos: a vitória de Leuctras e a de Mantinéia"; ao ser retirado o dardo que estava em seu peito, expirou em paz (BH, XV, LXXXVII, 6). Os oráculos e suas previsões serviam para mostrar ao leitor que os "grandes homens" sabiam aceitar seu destino com grandeza de espírito e sabedoria. Epaminondas morreu, mas seu nome teve o direito de figurar para a posteridade, não deixando jamais de "inspirar os bons e provocar nos maus, o temor da desonra". A narrativa segue, ainda, a linha homérica de relatar batalhas: suspensão do tempo e dos acontecimentos para que o herói tenha uma "bela morte" e oportunidade de, em seus derradeiros momentos, conferir maior significado aos atos realizados em vida.

A história de Tebas não terminara, contudo. Diodoro prossegue seu relato sobre a cidade tomada por Alexandre Magno (335-334), que já anunciara no livro XV. Primeiramente, sua narrativa inspira no autor a mais completa solidariedade para com os tebanos, não obstante sua declarada simpatia pelo Conquistador. Os signos divinos são fartos na narrativa, revelando aos tebanos toda a desgraça que se avizinha. Diodoro leva o leitor à mais profunda compaixão por Tebas e seu cruel destino.

Assim que Alexandre assumiu o trono da Macedônia, agiu com ímpeto junto às cidades gregas, que acreditavam que sua mocidade e pouca experiência nas lides militares e políticas o incapacitariam a agir com virtú diante da Fortuna inesperada. ${ }^{17}$ Sufocou rapidamente e com violência todas as revoltas nas póleis gregas, alternando com momentos de diplomacia. Seu maior interesse era partir para a conquista da Pérsia, projeto já acalentado por seu pai, antes do desfecho trágico de seu assassinato. Alexandre buscava a glória (dóxeis) e via as revoltas intestinas da Grécia e vizinhos como estorvos aos seus interesses

\footnotetext{
17 Mas Alexandre não era um neófito: já tinha combatido com seu pai Felipe e tomado interinamente seu lugar. Diodoro narra a vida de Felipe no livro XVI.
} 
maiores. Quando pensava que todos os problemas estivessem resolvidos, eis que novas ondas de sublevações explodem, especialmente em Tebas. O rei, irritado com esse "aborrecimento", envia imediatamente para lá uma guarnição macedônica, instalada na Cadméia, marchando pessoal e rapidamente com ela, para assediar Tebas. Entrementes, os tebanos cercaram a região com paliçadas e despacharam embaixadores por toda a Grécia, com pedidos de ajuda. Negociaram com argivos, eleus e também com Atenas que, na figura do grande orador Demóstenes, deu grande quantidade de armas para a resistência tebana. Os lacedemônios também mandaram soldados para o istmo; na realidade, tal ajuda mostrou-se extremamente ilusória, tendo em vista que os atenienses prometeram dar o que não tinham e os peloponésios, com guarnições macedônias em Corinto e Sicione, sob a pressão de Antípatros (estratego macedônio e homem de confiança de Alexandre), não podiam fazer muita coisa. ${ }^{18}$ Havia transcorrido pouco tempo da assinatura do Tratado de Corinto, que previa em suas cláusulas a tentativa de garantir uma "paz comum". De toda maneira, os possíveis "salvadores" de Tebas resolveram esperar pelo desenrolar dos acontecimentos, para saber que posição tomar. Diante do temor (terror seria mais apropriado) inspirado por Alexandre, ninguém se atreveria a tomar partido pró-Grécia, sem, antes, ter certeza de que lado o vento soprava. Quando os tebanos se depararam com as tropas macedônicas, tiveram grande medo, porquanto observaram sua superioridade evidente. Rapidamente, convocaram um conselho com o objetivo de discutir quais atitudes tomarem: unanimemente decidiu-se pela guerra e lutar até o fim por sua independência, a decisão foi aprovada pelo povo, ardorosamente determinado a combater. ${ }^{19}$ Alexandre deu tempo para que os tebanos mudassem de ideia, o que não ocorreu; ele pensava que ninguém teria a audácia de afrontá-lo, ainda mais uma única cidade! Tentou-se o caminho da negociação que, no entanto, não logrou êxito; foi dada a "oportunidade" para os tebanos que quisessem desertar e ficar ao lado dos macedônios, o que, entretanto, também não ocorreu. Diodoro intenta mostrar ao leitor que a honra de uma cidade estava em jogo. Se fosse para morrer, que morressem, sem a desonra da deserção. A audácia tebana parecia não ter limites. Do alto das muralhas, proclamaram: “Quem quer que deseje, junto com os tebanos e o Grande

${ }^{18}$ Com a partida de Alexandre para a Ásia ficou encarregado de cuidar dos negócios da Europa como seu estratego.

${ }^{19}$ Goukowsky ressalta que não houve unanimidade na decisão do "povo", até porque a constituição tebana era oligárquica. De toda maneira Diodoro procura tirar proveito de sua construção histórica para mostrar que na calamidade que atingiu Tebas, todos "estavam unidos" no infortúnio. 
Rei, libertar os gregos e depor o tirano da Grécia, precisava apenas ir até eles" (Biblioteca Histórica, XVII, IX, 5) 20. Alexandre sentiu-se extremamente ferido e ofendido; tomado pela cólera, decidiu, naquele momento, aniquilar Tebas, não sem antes infligir-lhes os maiores sofrimentos e castigos. Preparou suas máquinas de guerra, para fazer o cerco à cidade. A Grécia inteira tremeu diante da situação e todos perceberam que nada podiam fazer, a não ser assistir à aniquilação tebana. Tal atitude dos tebanos era extremamente temerária procurando por si próprios a própria desgraça e ruína. Eles pareciam não se importar ou se dar conta dos perigos que corriam e se preparavam para a guerra, com o coração desejoso de luta. Então, os deuses começaram a mandar presságios, procurando avisá-los do que realmente iria acontecer.

Descobriu-se uma fina teia de aranha no santuário de Deméter: tinha a dimensão de um manto e mostrava, nas suas bordas, um círculo semelhante ao formado pelo arco do céu. O oráculo de Delfos deu a seguinte resposta: "Esse signo (sēmeîon), os deuses o manifestam a todos vós mortais, aos beócios, sobretudo, assim como a seus vizinhos" (BH, XVII, $X, 2)$. O oráculo tebano lhes deu a seguinte resposta: "Uma teia se tece para a felicidade de um e a infelicidade do outro" (BH, XVII, X, 2). Esse signo foi recebido três meses antes da chegada de Alexandre; no momento em que ele se aproximava da cidade, notou-se que as estátuas da ágora estavam suando e em pouco tempo elas estariam cobertas de grossas gotas. Dos pântanos de Onquestos, ouviu-se um som parecido com gemidos, no rio Dircé, um fio de sangue corria sobre a água; outros, ainda, chegados de Delfos, revelaram que se via sangue sobre o telhado do templo construído pelos tebanos com os despojos dos focídios. Os especialistas na interpretação dos signos afirmaram que a teia da aranha anunciava a partida dos deuses da cidade; a coloração do arco do céu, uma tempestade de diversas calamidades e o suor das estátuas, um acontecimento fora do normal e, finalmente, o sangue aparecido em diversos lugares diferentes anunciavam que uma grande carnificina ocorreria na cidade. Como os deuses estavam avisando claramente as desgraças ${ }^{21}$ de que a cidade seria vítima, aconselhavam que não se

20 O "medismo" dos tebanos sempre foi ressaltado por autores gregos, incluindo Heródoto. Ele terá papel importante no desfecho da tragédia tebana. Os relatos tebanos de Diodoro utilizam não o estilo indireto comum a toda a sua narrativa, mas os acontecimentos são tão importantes, que reproduzem o discurso dos protagonistas, o que causa, sem dúvida, forte efeito dramático. Ver BH, XI, XXVIII, 3, XI, XXIX, 1,XI, XXX, e XXXIII, sobre o "castigo" infligido aos tebanos por seu "medismo".

21 No cerco à cidade de Tiro, acontecimentos semelhantes também ocorreram: os habitantes tiveram uma visão de que Apolo estava abandonando a cidade. 
corresse o risco de uma batalha ser decidida através de uma guerra. Melhor seria mandar embaixadores para tentar resolver a situação de uma maneira mais segura (Biblioteca Histórica, XVII, X, 4-5), ou seja, por vias diplomáticas. Mas os tebanos não se deixaram convencer: lembraram os gloriosos dias da batalha de Leuctras que, embora dificílimas, haviam logrado a vitória de maneira inesperada (anelpístōs) e miraculosa (thaumastôs), graças unicamente à sua coragem. Em sua exaltação patriótica, haviam perdido completamente a prudência, em detrimento da coragem.

Os preparativos para o cerco, organizados por Alexandre, duraram cerca de três dias. ${ }^{22} \mathrm{O}$ Conquistador dividiu seu exército em três corpos: o primeiro tinha a ordem de atacar as fortificações estabelecidas diante da cidade; o segundo, de travar batalha diretamente com os tebanos; o terceiro funcionaria como reserva para os soldados que viessem a faltar. De seu lado, os tebanos colocaram seus cavaleiros no interior da fortificação construída e opondo-se a eles, metecos e banidos nas muralhas. Mulheres e crianças correram para os santuários, a fim de suplicar aos deuses que salvassem a cidade de todo perigo. As trombetas tocaram o sinal para iniciar o combate; de ambos os lados, ouviram-se gritos de guerra e uma luta foi travada no corpo-a-corpo, dando início a uma grande carnificina. Era praticamente impossível resistir à pressão macedônica, em razão de seu número e o peso da falange. Os tebanos resistiam, devido à sua coragem e à prática regular de exercícios físicos, mas o número de feridos e seus gritos de dor ecoavam por todo o campo. Gritos exortavam os macedônios "a não manchar sua reputação vergonhosamente e sua bravura do passado" e os tebanos "a não deixar seus filhos e parentes correr o risco de serem reduzidos à escravidão, nem sua pátria sucumbir sob os golpes furiosos dos macedônicos! Eles deviam, ao contrário, lembrar-se das batalhas de Leuctras e Mantinéia [...]" (Biblioteca Histórica, XVII, XI, 5). O valor dos tebanos deixou

Acontecimentos extraordinários (parádoxon) e outros prodígios provocavam o pânico generalizado na multidão. Os cidadãos fizeram correntes de ouro para amarrar nos pés do deus afim de que não abandonasse a cidade. Do lado dos macedônios não era diferente: preparando-se para o cerco, viram monstros marinhos de incríveis dimensões que, entretanto, não lhes causou nenhum mal. Aqueles que viram semelhante espetáculo extraordinário (parádoxon) ficavam vivamente impressionados: cada um dos lados viu a aparição como a manifestação de Posêidon a seu favor (BH, XVII, XLI, 5-6).

${ }^{22}$ Goukowsky afirma que a narrativa de Diodoro causa ceticismo devido à rapidez dos preparativos. O editor do livro XVII afirma ter a narrativa de Diodoro um caráter claramente retórico. É exatamente por isso que ela me interessa. A narrativa é totalmente coerente com o conceito de história tão bem explicitado em seu proêmio no livro I, de incitar os homens a uma «aretē moral». Livro XVII, p. 172, n. XI, 1. 
indecisos por alguns instantes, os rumos da batalha. Alexandre, que a tudo assistia, vendo o ardor com que os tebanos defendiam sua liberdade e a lassidão que tomava conta dos macedônicos, ordenou aos reservas que entrassem em campo, uma vez que seu exército sofria graves perdas. Os tebanos estavam cada vez mais convencidos de que podiam vencer o exército macedônico e desprezavam qualquer perigo iminente, afirmando ainda que "os macedônios se reconheciam inferiores aos tebanos". Observando que, no meio da confusão geral, durante o corpo-a-corpo, a porta que dava acesso à cidade estava desguarnecida, Alexandre mandou Pérdicas, um de seus melhores generais, e um número suficiente de soldados, para se introduzir de surpresa na cidade. No exato momento em que os tebanos haviam colocado fora de combate a primeira falange macedônica e resistiam vigorosamente à segunda com grande esperança de conseguir a vitória, são supreendidos com a cidade tomada pela guarnição de Pérdicas. A cavalaria fez rápido movimento de retorno para a cidade, com o intuito de defendê-la, o que, em meio à confusão geral, causou grande mortandade entre seus próprios compatriotas, esfolando-os sob as patas dos cavalos. Ao saírem da cidadela, os soldados macedônicos massacraram os tebanos que estavam retornando.

O relato de Diodoro é pleno de humanidade e compaixão: os macedônicos fizeram uma proclamação que objetivava tratar os tebanos de maneira mais cruel do que se tratam os piores inimigos. Longe de se mostrarem covardes, os tebanos não se ajoelharam diante das tropas macedônicas, nem pediram clemência. Pelo contrário, ofereciam-se para receber os golpes; de fato, eles tinham na alma o espírito da liberdade e estavam longe de se ajoelhar diante da arrogância macedônica (Biblioteca Histórica, XVII, XIII, 1-2). Mulheres e crianças foram massacradas, sem qualquer piedade e, para isso, contaram com a ajuda dos próprios gregos "não obstante seu parentesco de raça". Muitas cidades que tinham ódio de Tebas aproveitaram o momento para se vingar, como os téspios, os plateus, os de Orcômeno e muitos outros. ${ }^{23}$ Tratava-se, Diodoro faz questão de ressaltar, de manifestações de ódio pessoal, em um momento que deveria inspirar compaixão:

${ }^{23}$ Em 373, os tebanos destruíram Plateias e pilharam os téspios. Em 364 destruíram Orcômeno, massacrando os homens e vendendo mulheres e crianças. Ambas as cidades foram restauradas por Felipe, pai de Alexandre. Tais atos praticados por Tebas provocaram a desaprovação geral na Grécia, o que explica em parte, a atitude em relação aos tebanos nesse momento. De toda maneira, o que Diodoro quer ressaltar nessa passagem é que, diante de tamanhos infortúnios, os homens de bem deveriam manifestar piedade magnânima diante do destino das vítimas, o que realmente é para poucos. Ver Livro XVII, n. XIII, 5, p. 174. O comentário de Goukowsky cita Xenofonte (Helênicas, 6, 3, 1) e remete ao próprio Diodoro em XV, XLVI, 5-6. 
"impiedosamente os gregos eram levados à morte e, não obstante seu parentesco de raça, eram massacrados por seus próximos, sem que a comunidade da língua fizesse experimentar aos últimos, a menor vergonha" (Biblioteca Histórica, XVII, XIII, 6). Foram mortos mais de seis mil tebanos e mais de trinta mil foram feitos prisioneiros; pilhou-se uma quantidade incrível de objetos preciosos. O rei reuniu-se com o conselho a fim de deliberar (ainda!) o destino que se deveria dar a Tebas. A opinião geral era de que Tebas deveria sofrer um castigo inexorável, demonstrando que, antes de servir aos interesses dos gregos, serviram aos interesses dos bárbaros (os persas): "no tempo de Xerxes, eles não combateram ao lado dos persas e fizeram campanha contra a Grécia? Não foram, somente eles, entre todos os gregos, foram honrados como benfeitores na corte persa, onde, diante do Grande Rei, dispuseram de poltronas para os embaixadores tebanos?" (Biblioteca Histórica, XVII, XIV, 1-2). Muitos outros lembraram episódios, em que os tebanos permaneceram contra a Grécia incitando o conselho (synédrion) ao ódio contra os mesmos. Foi deliberado "que se destruiria a cidade completamente, vendendo os prisioneiros, que na Grécia inteira os tebanos no exílio seriam passíveis de extradição, que nenhum grego poderia dar asilo a um tebano" (BH, XVII, XIV, 3). A cidade foi destruída, a fim de que servisse também de exemplo, para que nenhum grego se atrevesse mais a se revoltar. Os prisioneiros foram vendidos e foi arrecadada a soma considerável de quatrocentos e quarenta talentos. Uma delegação foi a Atenas, com o objetivo de reclamar a extradição de dez oradores que realizavam políticas hostis aos macedônicos, entre os quais Demóstenes e Licurgo. A cidade foi tomada por um grande embaraço e uma viva ansiedade: por um lado procuravam resguardar o prestígio da cidade, mas, por outro lado, a ruína de Tebas havia provocado sentimentos de temor: teriam tais desgraças realmente acontecido? Era impressionante que tamanho horror e infortúnio tivesse acontecido a seus vizinhos. Numerosos discursos foram pronunciados na assembleia convocada e, Fócio, considerado "Homem de Bem", que levava uma política oposta à de Demóstenes, afirmou que os tebanos deveriam imitar o comportamento de Leos de Jacinto, que procurara voluntariamente a morte pela pátria. Aqueles que não pretendiam morrer por ela eram uns covardes e faltavalhes virilidade. Mal acabou de pronunciar tais palavras, foi escorraçado pelo povo da assembleia, com manifestações tumultuosas que o desaprovaram totalmente. Demóstenes tomou a palavra, e com discurso cuidadosamente preparado, convenceu o povo, incitando-os a terem piedade, mostrando claramente que tais homens deveriam ser salvos. Demarade propôs salvar quem estava em perigo e redigiu de maneira hábil um documento em favor dos oradores, prometendo castigar, conforme as leis, aqueles que mereciam punição. $O$ povo aprovou o documento redigido e o ratificou; acompanhado de outros, enviou o decreto a Alexandre, 
perguntando também a propósito dos exilados tebanos, se os atenienses tinham o direito de recolher os fugitivos. O talento oratório de Demóstenes obteve completo sucesso e convenceu Alexandre em concordar com as proposições. Segundo Goukowsky (Diodore de Sicile, 1976: 27), as coisas não se passaram de maneira tão simples como Diodoro narra. Foram necessárias ao menos duas embaixadas sucessivas, das quais a primeira foi mal acolhida. Penso que Diodoro prefere adotar a narrativa de que "as coisas foram mais fáceis", em parte para "salvar" a imagem de Alexandre, que se deixou levar pela cólera e não era bem o que se poderia chamar de "grego" a despeito de sua primorosa educação helênica. Fica claro na narrativa diodoriana que Alexandre, apesar de seu declarado filohelenismo, estava interessado mesmo em seus projetos pessoais e usava os gregos para atingi-los. Nesse sentido, analisá-lo sob a ótica maquiaveliana, de que o mal deve ser aplicado de uma única vez e o bem aos poucos, exprime bem a personalidade do Conquistador. Escrevendo já na época romana, Diodoro mostra, em sua história universal o papel importante desempenhado pelos gregos, sobretudo como força moral de exempla. Não se furta de contar as desgraças da Grécia, de momentos terríveis, em que "gregos mataram gregos", ou da odiosa Tirania dos Trinta em Atenas (livro XIV), momento em que os lacedemônios agiram de maneira abominável. Percorrendo a Biblioteca Histórica, percebemos a profunda admiração que a história grega lhe inspirava, e grande parte de sua obra é dedicada à Grécia, a seus grandes homens e a seus grandes feitos. Poderia a Grécia ser modelo para a oikouménē? Penso que a resposta é positiva e os presságios e acontecimentos miraculosos que permeiam sua narrativa "grega" têm papel importante na organização interna de seu projeto de história tão bem explicitado no proêmio. "É graças à história [e à eloquência] que os gregos se sobressaíram sobre os bárbaros, as pessoas cultivadas sobre os seres ignorantes. É ainda graças a ela que um só homem pode dominar uma multidão" (Biblioteca Histórica, I, II, 6). Nada melhor do que narrar a história (sobretudo grega) para incitar os homens (gregos e populações helenizadas e os romanos em especial) a uma ética prática: é oportunidade única ver agir os grandes homens nas dificuldades da vida e diante de situações inesperadas que a Fortuna, caprichosa, coloca nos caminhos a serem percorridos por eles. $\mathrm{O}$ "acaso" contribui para que Diodoro possa explicar melhor a história de Epaminondas e inseri-la em seu projeto de história: aqueles que agem bem nas situações adversas são agraciados pelo "acaso". A felicidade de poder morrer junto às mais altas glórias que uma "bela morte" proporciona, deixando atrás de si o feito notável de Leuctras e Mantinéia, faz de Epaminondas herói inconteste da Biblioteca Histórica. 


\section{Fontes antigas}

HERÓDOTO: Histórias. Lisboa: Edições 70, 1994. Tradução de Maria de Fátima Silva e José Ribeiro Ferreira.

HESÍODO. A teogonia em português. HESÍODO; Teogonia. São Paulo: Iluminuras, 1991. Tradução de Jaa Torrano.

DIODORE DE SICILE. Bibliothèque Historique. Paris Les Belles Lettres, Livro XVII,1976.

\section{Referências bibliográficas}

ALBRECHT em Der kleine Pauly. Muechen. Deutscher. Taschenbuch Verlag, 1979.

CANFORA. A biblioteca desaparecida. Histórias da Biblioteca de Alexandria: São Paulo: Cia das Letras, 2001.

CLAUSEWITZ. Da Guerra: São Paulo: Martins Fontes, 2003.

FARRINGTON. Diodorus Siculus. Universal Historian. Swansea, 1937, p. 5 apud LENS-TUERO. Sobre la naturaleza histórica de la Biblioteca Histórica de Diodoro de Sicília. Granada: Universidad de Granada,1994.

GOUKOWISKY,PAUL. Notice. In: Bibliothèque Historique. Livre XVII. Paris: Les Belles Lettres, 1976.

Introduction. In: Bibliothèque Historique. Livre XVII. Paris: Les Belles Lettres, 1976.

HOWATSON (Dir.). Dizionario delle letterature classiche. Torino: Giulio Einaudi, 1993.

LEGRAND, Ph.-E. In: HÉRODOTE. Histoires. Paris: Les Belles Lettres, 1967, v. III.

MEISTER, Klaus. Diodorus Siculus. Der Neue Pauly. Enzyklopädie der Antike. Editado por von Hubert Cancyk und Helmuth Schneider. Altertum V. III. Stuttgart \& Weimar: J. B. Metzler, 1997. p. 592-594.

PÖTSCHER. Tychē. In: Der kleine Pauly. Muechen. Deutscher. Taschenbuch Verlag, 1979. V. 5. Schaf-Zythos, pp. 1016-1017.

ROMILLY. História e razão em Tucídides: Brasília: UnB, 1998. 
SCHWARTZ. Griechische Geschichtsschreiber. Diodoros von Agyrion. In: Real-Enciclopädie der Classischen Altertum Swissenschaft. Stuttgart: J. B. Metzer Verlag, 1903. v. 9.

SPOERRI, Walter. Diodorus Siculus von Agyrion (Sizilien). In: Lexikon der Alten Welt. Duesseldorf: Albatroz/Patmos Verlag, 2001. 